\title{
Are master plans effective in limiting development in China's disaster-prone areas?
}

\section{Citation}

Kim, Saehoon and Peter G. Rowe. 2013. Are master plans effective in limiting development in China's disaster-prone areas? Landscape and Urban Planning 111: 79-90.

\section{Published Version}

http://dx.doi.org./10.1016/j.landurbplan.2012.12.001

\section{Permanent link}

http://nrs.harvard.edu/urn-3:HUL.InstRepos:10671400

\section{Terms of Use}

This article was downloaded from Harvard University's DASH repository, and is made available under the terms and conditions applicable to Open Access Policy Articles, as set forth at http:// nrs.harvard.edu/urn-3:HUL.InstRepos:dash.current.terms-of-use\#OAP

\section{Share Your Story}

The Harvard community has made this article openly available.

Please share how this access benefits you. Submit a story.

Accessibility 
Are Master Plans Effective in Limiting Development in China's Disaster-Prone Areas?

Saehoon $\mathrm{KIM}^{\mathrm{a}^{*}}$ and Peter G. ROWE

${ }^{a}$ Department of Urban Planning and Design, Graduate School of Design, Harvard University, Cambridge, $M A$

48 Quincy Street, Gund Hall, Room 325A, Graduate School of Design, Harvard University, Cambridge, MA 02138, USA

Phone: 1-617-999-9923 / Fax: 617-495-0446 / Email: skim5@gsd.harvard.edu

${ }^{b}$ Department of Urban Planning and Design, Graduate School of Design, Harvard University, Cambridge, $M A$

48 Quincy Street, Gund Hall, Room 325A, Graduate School of Design, Harvard University, Cambridge, MA 02138, USA

Phone: 1-617-495-4237 / Fax: 617-495-0446 / Email: prowe@gsd.harvard.edu

*Corresponding author: Saehoon Kim 


\section{Highlights}

- The effectiveness of adopting urban master plans to limit development in disaster-prone areas was empirically tested for China's Yangtze River Delta region over the past thirty years.

- Environmental risk modeling was conducted to estimate the cumulative scope of urban built-up land located in highly hazardous areas.

- Master plans, especially when the pattern of urban development shows high compliance with master plans' preservation zoning, have a significant effect on limiting development in high-risk areas.

- The effect of master plans was not significant in a region vulnerable to high risks from multiple environmental hazards.

- Locational adjustment through municipal planning may avoid large-scale property losses from unexpected environmental hazards during the rapid development phase of a city. 


\section{Introduction}

Multi-billion-dollar disasters_-a flood in Bangkok, a tsunami in Sendai, a hurricane in New

Orleans - have devastated cities worldwide in the last ten years. Large-scale risks associated with environmental hazards may test a government's preparedness across a wide spectrum of planning issues, including land-use, transportation, and the provision of power supply, medical services,

food and shelter. Among these, the locational adjustment of housing, industries, and roads

through planning control is probably the most cost-effective governmental intervention,

especially under favorable socio-political circumstances. However, it is unclear how different components of master planning counteract urban spread over areas with multiple environmental hazards during periods of rapid urban development. Do master planning exercises, even without adopting articulated measures of disaster-prevention or compulsory insurance systems, benefit a community that would otherwise expand into disaster-prone areas?

This paper intends to broaden the findings of previous research on the relationship between master planning and environmental hazards by examining examples in a Chinese context. A regression-based study of 176 local governments in the United States by Burby and Dalton (1994) indicated that a local government, under state-planning mandates, is more likely to adopt land-use planning measures for disaster mitigation. In China, local governments were empowered with strong control over land-use conversions under the central quota-allocation system in the 1980s, although explicit measures of localized disaster prevention were adopted later. Also, more recently, local governments’ capitalistic engagement with land conversion has demonstrated a strong supply-side influence on urban development. Thus, this paper focuses on 
24 the compliance of Chinese cities' actual land-cover patterns with their master plans, rather than

25 describing whether or not state mandates for zoning were adopted by local governments. From a

26 methodological perspective, multiple spatial databases, such as high-resolution aerial

27 photographs, remote-sensed images, and master plans from 1980s' China, were georeferenced using map-overlay techniques to create a normalized environmental risk map across the Yangtze River Delta region. The objective was to illuminate the urban-planning factors associated with cumulative urban development in disaster-prone areas.

In China and elsewhere, master plans often become victims of their own merits, such as “comprehensiveness” in approach and so-called "rationality” in interpreting public interests. The

34 stated role of master plans is to coordinate the collective wishes of the community and different development proposals made by specialized planners in light of the overall goals of a society. Yet, master plans are often regarded as window-dressing exercises, being too general to be supported by serious political commitments and having fragile links to actual development outcomes (Altshuler, 1965). Friedmann (1971) referred to comprehensive planning as a “colossal failure,” criticizing it for pursuing an abstract common good while ignoring the fine-grained needs of localities. Even from an empirical perspective, master planning was viewed as a necessary, but hardly sufficient tool for guiding urban development. An investigation of 30 U.S. comprehensive plans by Berke and Conroy (2000), for instance, found no significant difference in how selected sustainability principles are supported between plans with stipulated environmental principles and plans without them. Nonetheless, master plans are still, and will continue to be, a critical expression of long-term public intentions for urban places. Governments worldwide make or advocate for master plans under different titles, such as chengshi zongti guihua in China (urban 
47 master plan) and tosi kibon kyehoek (city basic planning) in South Korea. Innes (1996) contends

48 that recent progress in consensus-building among stakeholders and planners has provided new

49 foundations for comprehensive planning. In other words, master planning per se is not

50 fundamentally flawed, as long as planners' substantive judgments can steer patterns of urban

51 development toward socially and environmentally favorable directions.

52

53 The so-called “second spring” of China's urban planning period in the 1980s, referred to by Leaf

54 and Hou (2006), provides a window for investigating the effects of master plans on land

55 development. By the end of 1984, 241 municipalities, or approximately 80\% of China’s cities,

56 had completed their master plans. These plans—aimed at making socialist modern cities-

57 incorporated planning measures such as coordinating future development between the city and its

58 countryside, designating special economic zones, defining city population size and overall

59 layouts of housing, industry, and road networks. The majority of the plans were codified in the

601984 City Planning Ordinance and approved by the State Council, which became influential in

61 shaping the physical layout of rapidly growing cities, along with other macro-level plans (Table

62 1). Although a master plan was not a legally binding document, development control measures,

63 e.g., site-selection notes, land-use and building permits, and penalties for illegal land occupations,

64 were adopted by city- and district-level planners in accordance with the approved master plans

65 (Yeh and $\mathrm{Wu}, 1998)$.

66

67 [Table 1 near here]

68

69 What remains unclear is what master plans have actually achieved without explicit measures for 
preventing large-scale, negative environmental hazards. In China, the annual costs of environmental disasters amounted to approximately 3-6\% of the national GDP between 1977 and 1994 (Yang, 2007). Although several government departments concerning disasters were established in the 1950s, coordinated efforts between the central government and local municipalities started much later (Li et al., 2010). The lack of disaster-prevention measures in the plans, however, does not mean that urban planners paid no attention to tragic consequences. Unlike the plans of the 1950s, the plans of the 80s were more responsive to a wide spectrum of public demands for a better quality of life. In the same period, investment in urban housing development rose rapidly and industries were relocated from densely populated urban districts. In a country where some $49.8 \%$ of total population lives in disaster-prone areas (World Bank, 2006), protecting people and lands from large-scale disasters remains a high priority, along with national concerns about people's livelihoods, food self-sufficiency, and promoting further economic growth. "Serving the people (wei renmin fuwu)" is not only a political slogan, but is often the modus operandi of Chinese leaders standing with the masses in need of immediate assistance.

Against this backdrop of China's urban planning, two specific questions were addressed in this article: Is compliance with master plans a significant factor that has limited urban developments in disaster-prone areas of the Yangtze River Delta region? How does the importance of master planning change as the definitions of a high-risk zone change? In accordance with the definitions established by Smith $(1996,5)$, this study employed three synonymous, but slightly different, terms such as "hazard," "risk," and "disaster." Hazard is a general and potential source of threat to humans, associated with natural or human-induced environmental events. Risk is the actual 
93 probability of a specific type of hazard. Disaster is defined as a manifest hazard that leads to the 94 death and injury of a large number of people and the damage of properties.

\section{Research methods: mapping master plans and environmental hazards}

The Yangtze River Delta region is located at $29^{\circ} 69^{\prime}-32^{\circ} 30^{\prime} \mathrm{N}$ and $118^{\circ} 39^{\prime}-122^{\circ} 36^{\prime} \mathrm{E}$ in a

101

102

103

104

105

106

107

108

109

110

111

112

113

114

115

transitional zone between the Yangtze River (Changjiang) and the East China Sea. The region’s alluvial land includes 44 cities and 1,730 towns, with a total of about 63 million householdregistered inhabitants. Urbanization in the Yangtze River Delta region has involved highly dispersed spatial patterns of land-cover change, along with a susceptibility to large-scale environmental hazards, in addition to a loss of valuable environmental resources due to outward expansion of cities and towns (Kim and Rowe, 2012). The region has shown great geomorphic dynamics, such as changes in the coast line and water bodies, as well as the occurrence of land subsidence dating back to the 1920s in Shanghai. These geological and hydrological features have been involved with the occurrence of earthquakes, landslides, and floods. Climatic change in the near future also poses a challenge, as some $55.3 \%$ of the inland Taihu watershed is made up of lowlands less than 3 meters above sea level (Sun and Mao, 2008). Population growth has been fairly incremental: the annual growth rate of total population in Shanghai was $2.32 \%$ between 1978-2010, whereas other provinces in the region showed a lower rate, e.g., $0.94 \%$ of Jiangsu, $0.74 \%$ of Zhejiang and 1.16\% of Anhui (Anhui Sheng tongjijubian, 2012; Jiangsu Sheng tongjijubian, 2012; Shanghai Shi tongjijubian, 2012; Zhejiang Sheng tongjijubian, 2012). Yet, 
116 the growth in the number of total households was much faster than population growth, due to the

117 decrease in average household size with simultaneous increases in population. In Jiangsu and

118 Zhejiang provinces, the number of households grew twice as fast as the overall population, at

$119 \quad 1.82 \%$ and $1.84 \%$, respectively.

120

$121 \quad$ 2.2. Data collection and analysis

122

123 In this study, five methodological steps were adopted to identify the components of master plans

124 that contribute to the limitation of development in disaster-prone areas. They were: (i) collection 125 of spatial data about major hazards, land-cover patterns, and master plans, (ii) quantification of 126 the degree of compliance between master plans and actual development patterns, (iii) generation 127 of an environmental risk map using appropriately scaled data, (iv) calculation of the size of urban 128 lands in high-risk zones using a stratified sampling approach, and (v) analysis of planning factors 129 associated with variations in areas of urban development at risk by way of the multiple 130 regression method.

131

132 Multiple databases were collected, including scanned 1980s master plans, multispectral remote133 sensed images from the late 1970s and 2000, aerial photographs, and other environmental 134 variables across the Yangtze River Delta region. Master plans were selected from an initial 135 sample of 96 cities in the four Chinese provinces of Shanghai, Jiangsu, Zhejiang, and Anhui, all 136 collected from Zhongguo chengshi dituji bianji weiyuanhui published in 1994 (Fig. 1). Shortages

137 of available master plans limited the number of cities from which data was collected, finally 138 leading to 24 cities and 23 towns near regional-level cities. Land cover in the study areas was 

$149 \mathrm{~m}^{2}$ cells.

extracted from Landsat images, such as Multispectral Scanner (MSS; $57 \mathrm{~m}$ resolution) and Enhanced Thematic Mapper Plus (ETM+; 30 m resolution), downloaded from the U.S. Geological Survey (USGS) Earth Resources Observation and Science Center. All images were geometrically rectified and re-projected with a 100 meter resolution. Supervised classification was then conducted to extract seven standardized land-cover classes, such as urban land, agricultural land, rangeland, forest, water bodies, wetland, and barren land. The outcome was compared with other spatial data, such as $1 \mathrm{~km}^{2}$ population-grid data acquired from the University of Michigan China Data Center. All layers were then georeferenced and digitized in ArcGIS to the Xian 1980 GK Zone 19 coordinate system. Although some original data have lower resolutions, it was assumed that the coarser value would be evenly assigned across all 100

\section{[Fig. 1 near here]}

$$
\text { How each city's actual urban pattern complies with its master plan was estimated based on five }
$$
urban-form giving factors: road patterns, average block size, the area of urban built-up lands, the locations of the three largest industrial sites, as well as the three largest preservation zones. The above-mentioned measures of compliance were selected based on each plan's prominent spatial features that were readily identifiable from the classified remote-sensed images. The road pattern and block size are indicators of a city’s urban structure and street network connectivity, which are widely used variables in the urban planning and transportation literature (e.g., Moudon et al., 2005; Brownson et al., 2009). The area of urban lands is a factor in the size of cities. Locations of industrial sites and preservation zones measure the degree of locational compliance between 
162 the planned and actual land uses. Further detailed criteria for the variables were as follows:

- The road pattern (0 or 1): If a ring road was present in compliance with a master plan, its value was coded as 1 . Throughout the 1980s and 90s, for instance, multiple ring roads were built in Chinese cities, such as Beijing and Shanghai's inner ring roads. size of planned and realized blocks were then recorded.

- The difference in the area of total built-up land (\%): The percentage of changes in the areas of urban built-up land between master plans and remote-sensed images were measured. From this a surplus of land that was actually developed, compared to what had been planned across all cities, was identified.

- The locations of major industries and preservation zones ( 0 or 1$)$ : The location of the three largest industrial and preservation zones was represented respectively as a binary variable. The value of 1 was given to each industry and preservation zone if all three planned zones were actually visible from remote-sensed images. Merging scattered industries into larger clusters, relocating them to satellite cities, and preserving largesized greenspaces were adopted in the master plans to shape the physical structure of Chinese cities. Throughout this paper, "preservation zones" refer to the sites that are protected for environmental or ecological conservation purposes through master planning guidelines. 
185 In order to create an environmental risk map, a multi-criteria suitability analysis was conducted.

186 This involved compiling data about five types of hazards: earthquakes, floods, landslides, land

187 subsidence, and sea-level rise (Fig. 2). These hazards were chosen based on the availability of

188 geospatial databases (Table 2). Moreover, China’s Agenda 21, which was adopted at the 1994

189 Executive Meeting of the State Council after the United Nations Rio Conference on Environment

190 and Development in 1992, described those hazards among the "major types of disasters" in

191 China (China’s Agenda 21, 1994).

192

193 [Fig. 2 near here]

194 [Table 2 near here]

195

196 Areas prone to earthquakes were mapped based on the distribution of fault lines digitized from

197 Guojia dizhenju dizhiyanjiusuo (1979). China is located between the Pan-Pacific and the

198 Eurasian seismic belts, and is potentially vulnerable to recurring earthquakes (Table 3). In the

199 study area, a M-5.0 earthquake occurred in Changshu in 1990, for instance, on one of the

200 mapped fault lines. Areas prone to flooding were drawn based on a map of a 1991 flood event

201 during the East Asian summer monsoon followed by heavy precipitation. Potential sites

202 vulnerable to landslides were mapped based on a combination of geo-environmental factors such

203 as lithology, the slope of lands, and land use (Gupta and Joshi, 1990). Areas afflicted by land

204 subsidence were mapped according to the study of Wu et al. (2008). They illustrated the

205 distribution of cumulative land subsidence in the Yangtze River Delta region between 1960-2000,

206 which was associated with intensive groundwater extraction from the second and third confined

207 aquifers. Lastly, areas potentially vulnerable to sea-level rise were mapped based on two 
different studies: a simulation study of areas directly impacted by sea-level rise conducted by Weiss et al. (2010), who assumed that by the year of 2100 at least 4-6m of sea-level rise will take place; and Gu et al. (2010), who mapped potentially inundated areas based on the assumption that the sea-level rise will be even more rapid—about $4 \mathrm{~m}$ by 2030. The latter assumed that most regions in Shanghai, the Taihu watershed, Nantong, and Jiaxing will be flooded, if sea walls with a height of 1-1.5m are not constructed. Both sets of spatial data were digitized with an equal weight, reflecting more or less equal importance to each mapped set of measurements.

\section{[Table 3 near here]}

Cumulative scores for disaster hazards were calculated by adding re-scaled values in location $i$. The risk score for each hazard variable $\left(D_{i}\right)$ was transformed between 0 (= no impact) and 1 (= the strongest impact) using a linear fuzzy operator in ArcGIS. This operator rescaled each raster value between 0 and 1 based on a distance threshold $d$ for input layers, enabling the addition of their standardized scores. The distance threshold for each hazard was defined as the average distance at which the intensity of the impact of certain hazards is reduced to being negligible (i.e., very weak or no impact). Although there is a fairly large variation in this threshold distance within the literature, recent findings by environmental scientists provide key insights for establishing working estimates. For instance, Bakun et al. (2005) calculated that the mean intensity of ground shaking during an earthquake dropped by one-third of the highest intensity when the distance from the fault line increased by $30 \mathrm{~km}$ or more. At this point, the peak horizontal acceleration (PHA) value of an earthquake fell below $0.1 \mathrm{~g}-\mathrm{a}$ threshold of weak to moderate land shaking that only lightly damages buildings—although the damage may also 
231 depend on the magnitude of earthquake per se. Based on this finding, a site located on a fault line 232 was given the maximum impact score $\left(D_{1}=1\right)$ for earthquake hazard. As the location of a site 233 moved away from the fault line, the value of $D_{1}$ decreases, leading to $D_{1}=0$ if $d>30 \mathrm{~km}$. For 234 estimating the threshold distance of floods, there is, unfortunately, no comparable research. A 235 distance of $10 \mathrm{~km}$ from major water bodies located in lowlands less than 3 meters above sea 236 level was used as a proxy for 100-year floodplains. This estimation was based on the average 237 distance between impacted areas from a 1991 flood in relationship to major water bodies in the 238 region. For other types of hazards, $1 \mathrm{~km}$ was applied as a threshold distance by default. 239 However, simply aggregating rescaled risk values may, in fact, underestimate the significance of 241 certain land cover in mitigating the magnitude of environmental events. For instance, mature 242 woody vegetation near roads absorbs excessive water flow during rainfall, which greatly reduces 243 flood hazards in downstream water bodies (Forman and McDonald, 2007). This environmental 244 benefit is more valuable if the function is rarely provided within the region. Thus, in this study, a 245 rarity-weighted index, or $w_{i, k}$, was proposed and applied to weigh the loss of specific land cover $246 L_{k}$ at a location $i$, so that more valuable land cover could be weighted more heavily. A logistic 247 function was then used to scale the rarity index between 1 (not rare) and 3 (rare):

$249 w_{i, k}=\frac{2}{1+e^{\left(t-\frac{T}{2}\right)}}+1$

251 where $t$ is the number of specific land-cover cells within the boundary of a city or a town and $T$ is 252 the total number of cells within the same area. There are two assumptions associated with this 
253 premise: forests mitigate risks associated with floods and landslides; and wetlands and water

254 bodies decrease the probability of floods by enhancing the hydrological capacity of a flood-prone

255 area. Other hazards like earthquakes, land subsidence, and sea-level rise were assumed to be

256 relatively independent of terrestrial land-cover types, thus a baseline weight of 1 was applied.

257 Cumulative environmental risk scores were calculated using the following conventional formula:

$259 \quad C_{i}=\sum_{k=1}^{q} \sum_{i=1}^{p} D_{i} \times L_{k} \times w_{i, k}$

260

261

262

263

264

265

266

267

268

269

270

271

272

273

274

275 The effects of master plans associated with urban areas in disaster-prone sites were assessed 
using the multiple regression method. Because master plans are likely to influence developments in the long run, it seemed more reasonable to use averages over a longer period than focusing on a single-year outcome. Accordingly, the average value of the normalized risk scores for the years of 2000 and 2010 was used as a dependent variable. Then, three different high-risk criteria were analyzed using the regression method with backward elimination, as the significance of variables could be sensitive to the definition of risk.

Also, besides the five key variables related to compliance with master plans, multiple historic and socio-economic factors were included. These covered: (1) municipal services and institutional capacity, e.g., density of sewers $\left(\mathrm{km} / \mathrm{km}^{2}\right)$, per-capita road areas maintained by governments $\left(\times 10 \mathrm{~m}^{2}\right.$ per person), and garbage treatment capacity (tons per day per 1,000 people). These variables were selected as a proxy for planning staff capacity and institutional commitments with regard to the prevention and mitigation of environmental disasters. (2) Demand for hazard mitigation, such as previous disastrous floods in 1951 and degrees of air pollution measured by the level of $\mathrm{PM}_{10}$. These variables were selected based on the notion that local governments in an area with recurring environmental threats would be more aware of the planning measures associated with other types of hazards. (3) Economic resources, such as percapita GDP in yuans in 2005 and the administrative hierarchy of cities (= 1 if regional-level cities). The exploitation of land and water resources for economic purposes may cause conflicts with environmental planning goals. (4) Barriers for controlling developments, e.g., population growth rate (\%) between 1997 and 2005, slope of lands, and the presence of mining sites (= 1 if present). These variables were selected as a proxy for human-created or geographical impediments to planning controls on urban development in disaster-prone areas. 


\section{Results}

\subsection{Compliance of master plans with urban development patterns}

Adopting master plans has a moderately significant impact on limiting urban developments in disaster-prone areas. A city showing high compliance with its master plan generally has a lower proportion of urban lands exposed to risks from environmental hazards, although no causal 307 relationship can be inferred from the result (Table 4). Among the five measures of master plans, 308 preservation zoning may have a particularly significant influence on limiting developments. For

309 instance, cities that have protected their planned preservation areas have, on average, $14 \mathrm{~km}^{2}$ less 310 urban land exposed to high risks according to the regression model (4). Preserved areas are 311 largely located in vegetated patches on steep hills or lowlands near water bodies—often having 312 high environmental value and amenity as well as being exposed to potential disaster risks.

314 Sensitivity analysis was conducted to test whether the significance of preservation zoning is a 315 result of the definition of a high-risk zone. Three different definitions - the top 15\%, 25\%, and $31650 \%$ risk scores within the region-were applied to estimate the areas of urban development in a 317 high-risk zone, and multiple regression analysis with backward elimination was conducted. The 318 results show that preservation zoning remain significant when relatively greater risks at the top 319 15\% and 25\% are accounted for (Table 5). Yet, when the definition was relaxed to include the $32050 \%$ scores, master planning did not seem to be a significant factor. These outcomes suggested 321 that complying with master plans, especially with preservation zoning, may be associated with 
322 mitigated vulnerability of urban lands related to fairly high risks. But if the vulnerability is

323 defined with a lower level of risks, there seems to be little room for master planning measures to 324 be effective.

325

326

[Table 4, 5 near here]

327

The total area of urban land is a second influential factor of master plans associated with developments, when municipal services and institutional capacity are controlled for in the regression model (2). But in other models, this variable was not significantly related to hazard risks. Also, not all dimensions of master plans were equally important. Compliance with ring roads, block sizes, or locations of major industries were not significantly associated with development outcomes of disaster risk. A joint hypothesis test using all five variables of master

334 plans supports this outcome. Their combined effect is not significant $(\mathrm{P}$-value $=0.399)$ at the $5 \%$ 335 significance level. The results indicate that complying with every aspect of a master plan does not necessarily lead to substantial planning gains vis-à-vis hazard protection, but adopting certain

337 elements of master plans such as preservation zoning and limiting total urban built-up areas may 338 benefit a city during its rapid expansion phase.

342 The significance of master plans becomes diminished when major historical flood events are 343 included. It is likely that compliance with plans plays a less important role in a region with 344 fundamentally high risks from multiple environmental disasters. In the sensitivity analysis, a 
345 historical flood event was the only variable found to be significant across all risk scores at the

346 1\% significance level (Table 5). Some lowlands below sea level near Taihu Lake and the eastern

347 coastal area of Shanghai and Chongming Island are potentially vulnerable to a multitude of

348 environmental hazards. The normalized risk score of a town like Huinanzhen in Shanghai or

349 Fuqiaozhen in Taicang, for instance, is about twice as high as a relatively safe site near Nanjing.

350 Areas to the eastern side of Gehu Lake in Changzhou have risk scores that are more than three

351 times higher than Nantong. Localized planning efforts in these areas may not eliminate all major

352 hazards. Regions widely differ in their basic vulnerability to disasters for reasons of geography,

353 climate, historic land uses, and cumulative investment in engineering projects. These

354 fundamental differences can hardly be neutralized through master planning.

355

356 This geographical impediment to successful land-use management is consistent with the outcome 357 of a recent country-level study by Kellenberg and Mobarak (2008). According to the study, the 358 inherent locations of countries, such as their proximity to coasts or fault lines, strongly affect the 359 impacts they suffer from environmental disasters. But an interaction between environmental 360 hazards and human responses can reverse this negative cycle. Indeed, some types of disasters 361 with adverse short-term impacts might eventually make way for a society’s positive economic 362 growth, as long as the impacts can be withstood with capital re-investment, increases in total 363 factor productivity, and technological innovations (Noy, 2009; Skidmore and Toya, 2002). For 364 instance, Horwich (2000) analyzed how the Japanese port city of Kobe could quickly recover 365 from the 1995 earthquake damage. The city's large-scale loss of physical capital could be quickly 366 rebuilt through various combinations of intensive capital reinvestment, as long as the majority of 367 human capital could be saved from losses. Therefore, geographical features are fairly influential, 
368 but not necessarily decisive factors in the success and/or failure of land-use management with

369 regard to environmental consequences.

371 3.3. Spatial distribution of environmental hazards in the Yangtze River Delta region

373 Predicted susceptibility of urban lands to disasters showed a fairly dispersed pattern in the

374 Yangtze River Delta region (Fig. 4). About 6.2\% of total urban land, or approximately $377 \mathrm{~km}^{2}$,

375 is located in highly disaster-prone zones with a cumulative impact score $>0.553$ ( $=25 \%$

376 definition). Shanghai, Jiaxing, Changshu and Wuxi are cities that are exposed to

377 disproportionately high risks from environmental hazards in absolute terms. In proportional

378 terms, however, eight out of the top ten cities in high-risk areas are actually towns (Fig. 5). Only

379 two cities_-Huzhou and Kunshan—have 20\% or more of their lands exposed to high risks

380 according to these proportional terms. The overall susceptibility of these ten places increases

381 rapidly as sites with the upper 50\% risk scores are defined as high risk: more than $80 \%$ of these

382 cities’ and towns’ urban lands are classified into high-risk areas.

383

384 [Fig. 4, 5 near here]

385

386 If individual cities are investigated, the wide variation in the spatial distribution of urban lands

387 exposed to environmental hazards is clearly illustrated. For instance, sites approximately 45-50

$388 \mathrm{~km}$ away from the center of Shanghai show the highest agglomeration of high-risk zones (Fig. 6).

389 These lands include the eastern part of Pudong, Dianshan Lake to the west of Shanghai, and the

390 G1501 suburban ring road. By contrast, Hangzhou and Wuxi demonstrate increasing 
391 vulnerability of urban lands to environmental disasters as the distance from their city centers

392 increase. Nanjing presents a rather even shape in the distribution of vulnerable lands across all

393 distances. The results indicate that urban plans for mitigating hazard impacts should be carefully

394 made according to the distribution of sites potentially vulnerable to different risks.

396 [Fig. 6 near here]

Large-scale infrastructural development projects, such as the Pudong International Airport, the Shanghai-Nanjing high-speed railway, and Kunshan New Hi-tech Industrial Development Zone seem to be highly vulnerable to environmental hazards. Although there is no evidence that these

401 projects actually increased the amount of property loss due to environmental disasters, intensive 402 capital investment by the State was one of the major drivers behind placing large-scale 403 infrastructure in hazardous areas. These perverse incentives took different forms, such as 404 government-friendly policies in Jiangsu province for hosting more than $10 \%$ of the nation's total 405 industrial land use in locations that are spatially correlated with areas impacted by land 406 subsidence; or the more recent $\$ 586$ billion stimulus package injected into transportation 407 infrastructure and housing development, some of which will be constructed in hazardous areas. 408 This national policy further escalated the growth curve of built infrastructure in China, as 409 exemplified by more than ten-fold increase in the length of the national road network between 4101978 and 2009 (Houjiezhubian jianshebu bangongting, 1997; Jianshebu zonghe caiwusibian, 411 2010). Undoubtedly, well-connected infrastructure does not fundamentally present a problem, i.e., 412 transport corridors can be used for swift evacuation during a crisis. Yet, excessive investment in 413 fixed assets may induce a negative cycle between a location’s dramatically improved 
414 accessibility and large-scale urban development in a highly disaster-prone area. In the regression

415 models, the positive correlation between the construction of ring roads and increases in

416 hazardous developments tends to support this argument, though this relationship is not

417 statistically significant.

418

419 4. Discussion

420

421 The risks from environmental disasters in China are extensive, various, and increasingly frequent.

422 Among the different regions of China, densely populated delta regions such as Yangtze, Huanghe, 423 and Zhujiang deltas are most vulnerable to the risks associated with flooding and land subsidence

424 (Syvitski et al., 2009). In the delta regions, vertical change in the level of land surface relative to 425 mean sea level has been striking for several reasons: sedimentation along the major rivers has 426 decreased rapidly; sea levels are rising; and human-induced subsidence associated with 427 groundwater pumping has taken a toll over the last 100 years. These causes of land subsidence, 428 along with coastal inundation from storm surges or flooding from rivers and lakes, may 429 aggravate potential environmental threats. At the same time, droughts and flooding have directly 430 affected more than 3\% of China’s total surface area in 2000 (Table 3). Droughts are believed to 431 be caused by both global climatic change and human-induced landscape transformation. The 432 removal of stream corridor vegetation and riparian forests disturbs the water cycle by interfering 433 with groundwater recharge. Also, excessive soil erosion and the resultant sedimentation in the 434 lower reach of rivers and lakes leads to the reduction of a region's water-holding capacity, 435 potentially making it vulnerable to both flooding and droughts. The Shanghai Key Laboratory for 436 Urban Ecology and Sustainability, for instance, recently initiated intensive research focusing on 
437 public safety, health, and social equity issues in recognition of the challenges on the path to 438 urban sustainability and environmental change (Xiang et al., 2011).

440 The results of the research present important findings from urban policy and planning

441 perspectives. Master planning, despite its often-criticized generality, may provide spatially

442 explicit guidelines for limiting or leveraging urban development away from unsuitable areas.

443 This planning intervention seems to be more important to limiting urban development in a high-

444 risk zone than in a low-impact zone. Locational adjustment through plans can also potentially

445 reduce negative consequences from environmental disasters if backed up by institutional support,

446 economic resources, and communities' self-protective actions, as reflected in the positive

447 influence of regional-level city variables in the regression models (4) and (5) in Table 4. Cities

448 like Nanjing, Yangzhou, Nantong, and Ningbo, for instance, are all regional-level cities with

449 fairly strong planning capacities and financial resources, interactively limiting land

450 developments in hazardous areas below the regional average level. From an urban design

451 perspective, design components such as road pattern and block size do not seem to affect cities’

452 macro-scale vulnerability to disasters.

453

454 In the face of those environmental hazards, the misplaced agglomeration of buildings and 455 infrastructure in a disaster-prone area can lead to tragedy. In this regard, structural prevention-

456 reinforcing building codes and maintaining the capacity of infrastructure-has been a

457 conventional approach for hazard mitigation. This preventive measure against property loss is

458 often accompanied by large engineering works, such as building reservoirs for flood mitigation

459 or making canals for reliable water supply. Yet, these policies are also subject to perverse 
incentives: subsidies that are adverse in the long run due to the development in disaster-prone areas through public investment. If coupled with systemic underestimation of unpredictable events, environmental disasters beyond salient design codes may ravage a large number of properties and cause loss of human lives. Facing the limitations of structural prevention, multiple methods have been proposed to deter further development in unsuitable areas through state mandates and land-use zoning (Burby and Dalton, 1994), as well as through multiple sociopolitical responses to unexpected events (Adger et al., 2005).

Despite the significance of diversifying a menu of choices for pre- and post-disaster responses, the effectiveness of mitigating hazardous impacts through land-use controls should not be underestimated. Avoiding intensive developments in disaster-prone areas is probably the most cost-effective measure in downsizing the cumulative cost of recurring disasters. Relocating people to a safer place after development is often prohibitively expensive. Furthermore, once a community or urban district constitutes an economic base for surrounding neighborhoods, reshaping its physical, social, and institutional circumstances requires a considerable amount of time and political will. In China and elsewhere, making master plans usually involves public hearings, expert consultation, municipal reviews, and approvals from the central government. Priorities in the locations of near-future development are shared among land owners, developers, bureaus, and households who all may have a limited capacity for differentiating among troubled and untroubled sites. Furthermore, fine-scaled neighborhood planning or “detailed control plans,” as they are labeled in China, can be integrated into master plans, allowing them to become more refined at the local level. Also, master plans may serve as guidelines for disaster mitigation by coordinating the extraction of resources. For instance, under the Regulations of 
Shanghai Municipality on the Administration of Water Supply, groundwater exploitation in

484 Shanghai is not allowed if any surface water source is available for use, or if an area has already

485 been affected by intensive groundwater extraction, or if the proposed site is located near

486 protected building structures (Shanghai Water Authority, 2006). These measures, if stipulated in

487 master plans, can mitigate land subsidence and protect groundwater sources by guiding

488 developers and land owners to adopt rainwater-harvesting and water-storage technology in the

489 early phases of land development.

490

491 In the Yangtze River Delta region, cities like Jiaxing, Changshu, Wuxi, and the coastal area of

492 Shanghai are exposed to disproportionately higher risks than other cities. Nonetheless, small-

493 sized towns like Dongshanzhen and Chengqiaozhen may be more vulnerable to potential hazards

494 like earthquakes, flooding, and sea-level rise due to their intrinsic diseconomies of scale and

495 geographical insularity. Small towns may also have high external transportation costs and time

496 delays in the provision of relief during disasters. Internal hazard-forecasting systems and relief-

497 fund programs are relatively weak compared to large cities. Additionally, productive assets,

498 infrastructure, and emergency shelters are often spatially concentrated in a few places. Therefore,

499 extending the resilience capacity of a metropolitan city to smaller towns and villages is very

500 important. Also, combining market-oriented incentives and regulatory frameworks for disaster

501 mitigation can bring mutual benefits to urban and rural areas. For instance, setting appropriate

502 prices for water resources, controlling the amount of groundwater exploitation, and ecological

503 planning such as reforestation and wetland protection can reduce environmental costs in the

504 urban regions.

505 
The majority of low-impact areas in the Yangtze River Delta region are located outside the jurisdiction of Shanghai and the Suzhou-Wuxi-Changzhou corridor, in cities such as Nanjing, Nantong, and Ningbo. These cities are not part of the Taihu watershed, and are less affected by recurring floods and land subsidence. On the other hand, master planning efforts have had a fairly strong influence on the patterns of urban spread of these cities. For example, Nanjing was one of the earliest cities where a Municipal Planning Bureau was re-established in November 1978, after the long demise of planning in China during the Cultural Revolution. There is a report on the Nanjing Master Plan, which was approved by the State Council in 1983, showing that, "Construction and redevelopment must be strictly in accordance with master planning...preserving the characteristics of ancient capital Nanjing as a socialist modern city (Nanjing Shi difangzhi bianzuanweiyuanhui, 2008).” Moreover, the plan-making process of the 1983 Master Plan of Nanjing involved a multitude of institutional agencies. Experts from the Nanjing Institutes of Technology and Geography, as well as other institutions such as Tongji and Tsinghua Universities, and a provincial-level planning commission convened by the chairman Yang Tingbao worked on the draft. The scope of planning was more inclusive of residential and social components than the earlier versions. Unlike the 1950s plan's narrow focus on Soviet-style industrialization, for example, the large scale of housing construction in the 1980s unfolded under the principles of residential districts (juzhuqu) —a template of large housing blocks and coarse-grained street patterns—described in the master plans.

The late 1980s was a period of economic, social and political turmoil in China. Economic fluctuations were followed by the central government's macro-economic adjustments through which housing properties and enterprises became incrementally privatized; the supply of basic 
resources like water and energy to urban sectors remained below municipal standards; and the remediation of negative socio-environmental damage was a daunting task. Therefore, strict compliance with master plans may be less attributable to a plan's theoretical legitimacy, and more to the pragmatic choices made by local municipalities in need of reasonably tested tools for coordinating large-scale urbanization. Between 1986-1990, the total floor area of newly constructed urban housing in China, for instance, was about 1,055 million $\mathrm{m}^{2}$. This volume, in turn, was equivalent to ample residential areas for a third of total urban residents in China, considering that there were some 301.9 million urban inhabitants in 1990 (NBS, 2011c). Under conditions of necessary housing development, conforming with a master plan appears to be a reasonable option vis-à-vis avoidance of environmental disasters.

One of the policy prescriptions for preventing losses from environmental disasters is to encourage households to relocate to safer places. In Beijing, for instance, a new countryside planning program was initiated in 2005 in conjunction with the Beijing Master Plan 2004-2020. Under this program, the central government provided financial subsidies to local municipalities to improve the living standards of the population, which initiated a comprehensive investigation of Beijing's some 4,000 villages. The preliminary results indicated that about 2 million people in 2,395 rural settlements are exposed to geological hazards such as earthquakes and landslides, and another 1.6 million people are located in unsuitable lands near water-quality protection zones or flood-prone areas. As a planning response, village settlements were classified into three zones: relocation (quan jian anzhi), rearrangement (chengzhen hua zhengli), and maintenance (baoliu fazhan) zones. Although this program is in process, considerable diversity in rural settlements, villagers' preferences, and the high costs of relocation have posed a great challenge to these 
552 efforts. Yet, on the other hand, diversity in villages can be exploited for selective resettlement.

553 According to Smith et al. (2006), different social groups respond to hazards in different ways,

554 i.e., wealthy households, who have the greatest self-protective capacity, are not likely to readily

555 relocate when faced with a probable hazard, whereas those in the middle class rather quickly

556 move out to avoid perceived disaster. Therefore, municipal planning action will be more

557 effective if it is flexible enough to adjust according to the individuals' differing perceptions of

558 their property and risks.

559

560 In 2010, more than 35\% of China’s large-sized industrial enterprises were located in the Yangtze

561 River Delta’s four provinces (NBS, 2011b). Certainly the region’s industrial specialization has

562 led to increased environmental degradation. Nonetheless, the other side of this also needs to be

563 highlighted. The locational choices of large firms became dramatically widened through

564 clustered development. Scattered supply chains, production units, and transportation

565 infrastructure are increasingly clustered under the local governments’ orchestration into big

566 industrial quarters like the Zhangjiang High-tech Park in Shanghai. Within the scope of this

567 analysis, the benefits of clustering industries seem to outweigh its costs, as long as their locations

568 are carefully chosen away from disaster-prone areas and other types of perverse incentives.

569

570 5. Conclusion

571

572 In this paper, a rarity-based environmental risk map was constructed to empirically test the

573 effects of master plans in limiting developments in disaster-prone areas. The results indicate that

574 cities showing high compliance with their master plans generally have smaller areas of urban 
575 land exposed to environmental hazards. Among the different planning elements, preservation 576 zoning is a significant factor associated with limiting developments. Other properties of urban

577 patterns such as the presence of a ring road, block size, and the locations of major industries have

578 no significant relationship to limiting developments with regard to disaster-prone areas. It seems

579 that physical planning plays an important role in limiting urban development in or near fairly

580 high-risk sites. However, in a region with very high risks from multiple environmental hazards,

581 planning compliance seems to play a less important role during the rapid development phase of a

582 city.

583

584 Although this paper presents the status quo estimates of the distribution of environmental

585 hazards, these estimates are incomplete for the following reasons. First, only a limited number of

586 hazards were included in this analysis, due to the constraints of data availability. Nonetheless,

587 this limitation in conceivable numbers does not necessarily negate the legitimacy of a suitability

588 model, since incorporating many variables with a high spatial correlation may lead to an

589 unjustifiable emphasis on a few hazard effects on the region. In this study, five variables were

590 relatively independent, which suggests that such inflation has a minimal impact on the model.

591 Second, aggregating different environmental risk scores may lead to a unitless value that is not

592 subject to any intuitive interpretation using conventional units of intensity. Yet, the purpose of

593 the model was to spatially differentiate locations with high environmental risks from sites with

594 relatively low risks, not calculating a singular index that standardizes all types of disasters. Third,

595 a full-scale environmental assessment can be made by not only calculating risk scores, but also

596 by addressing the vulnerability of buildings and the exposure of different social groups to risks.

597 If parcel-level data bases of Chinese cities become available in the near future, this approach 
598 may reveal more useful information about the interactions amongst government planning,

599 environmental conditions, and community responses. Fourth, this research assessed master plans

600 based on a set of standardized land-cover classes. Applying more fine-grained land-cover

601 classification systems may reveal some variations in the compliance of a city's urban pattern

602 with its plan, such as differences in the degree of compliance between road patterns and housing 603 developments.

604 


\section{References}

Adger, W.N., Hughes, T.P., Folke, C., Carpenter, S.R., Rockström, J., 2005. Social-ecological resilience to coastal disasters. Science, 309(5737), 1036-1039.

Altshuler, A., 1965. The goals of comprehensive planning. Journal of the American Institute of Planners, 31(3), 186-195.

Anhui Sheng tongjijubian, 2012. Anhui tongji nianjian 2011 (Anhui Statistical Yearbook 2011). Zhongguo tongji chubanshe, Beijing. [in Chinese].

Bakun, W.H. et al., 2005. Implications for prediction and hazard assessment from the 2004 Parkfield earthquake. Nature, 437(7061), 969-974.

Berke, P.R., Conroy, M.M., 2000. Are we planning for sustainable development? Journal of the American Planning Association, 66(1), 21-33.

Brownson, R.C. et al., 2009. Measuring the Built Environment for Physical Activity: State of the Science. American Journal of Preventive Medicine, 36, S99- S123.e12.

Burby, R.J., Dalton, L.C., 1994. Plans can matter! The role of land use plans and state planning mandates in limiting the development of hazardous areas. Public Administration Review, 54(3), 229-238.

Changjiang Water Resources Commission, 1999. Changjiang liuyu dituji (Atlas of the Changjiang River Basin). Zhongguo ditu chubanshe, Beijing. [in Chinese].

China's Agenda 21: White Paper on China's Population, Environment, Development in the 21st Century, 1994. China Environmental Science Press, Beijing.

Forman, R.T.T., McDonald, R.I., 2007. A massive increase in roadside woody vegetation: goals, pros, and cons. Proceedings of the 2007 International Conference on Ecology and Transportation, Center for Transportation and the Environment, North Carolina State University, Raleigh, NC.

Friedmann, J., 1971. The future of comprehensive urban planning: a critique. Public Administration Review, 31(3), 315-326.

Gong, P. et al., 2010. China’s wetland change (1990-2000) determined by remote sensing. Science China Earth Sciences, 53(7), 1036-1042.

Gu, C., Zhang, X., Wang, X., Guo, J., Hu, I.L., 2010. Climate change and urbanization in the Yangtze River delta. Lincoln Institute of Land Policy Working Paper, Cambridge, MA.

Guojia dituji bianzuan weiyuanhui, 1993. Zhonghua Renmin Gongheguo guojia jingji dituji (China National Economic Atlas). Zhongguo ditu chubanshe, Beijing. [in Chinese].

Guojia dizhenju dizhiyanjiusuo, 1979. Zhonghua Renmin Gongheguo dizhen gouzaotu (Seismotectonic Map of the People's Republic of China). Zhongguo ditu chubanshe, Beijing. [in Chinese].

Guojia tongjiju renkou tongji sibian, 1993. Zhongguo renkou tongji nianjian 1992 (China Population Statistics Yearbook 1992). Zhongguo zhanwang chubanshe, Beijing. [in Chinese].

Gupta, R.P., Joshi, B.C., 1990. Landslide hazard zoning using the GIS approach: a case study from the Ramganga catchment, Himalayas. Engineering Geology, 28, 119-131.

Horwich, G., 2000. Economic lessons of the Kobe earthquake. Economic Development and 

Cultural Change, 48(3), 521-542.

Houjiezhubian jianshebu bangongting, 1997. Zhongguo chengxiang jianshe fazhanbaogao (China Urban and Rural Construction Development Report). Zhongguo chengshi chubanshe, Beijing. [in Chinese].

Innes, J.E., 1996. Planning through consensus building: a new view of the comprehensive planning ideal. Journal of the American Planning Association, 62(4), 460-472.

Jiangsu Sheng tongjijubian, 2012. Jiangsu tongji nianjian 2011 (Jiangsu Statistical Yearbook 2011). Zhongguo tongji chubanshe, Beijing. [in Chinese].

Jianshebu zonghe caiwusibian, 2006. Zhongguo chengshi jianshe tongji nianjian 2005 (China Urban Construction Statistical Yearbook 2005). Zhongguo jianzhu gongye chubanshe, Beijing. [in Chinese].

Jianshebu zonghe caiwusibian, 2010. Zhongguo chengxiang jianshe tongji nianjian 2009 (China Urban and Rural Construction Statistical Yearbook 2009). Zhongguo jianzhu gongyechubanshe, Beijing. [in Chinese].

Kim, S., Rowe, P.G., 2012. Does large-sized cities’ urbanisation predominantly degrade environmental resources in China? Relationships between urbanisation and resources in the Changjiang Delta Region. International Journal of Sustainable Development \& World Ecology, 19(4), 321-329.

Kellenberg, D., Mobarak, A.M., 2008. Does rising income increase or decrease damage risk from natural disasters? Journal of Urban Economics, 63(3), 788-802.

Leaf, M., Hou, L., 2006. The "Third Spring” of urban planning in China. China Information, 20(3), 553-585.

Li, J., Chen, Y., Gong, A., Jiang, W., 2010. Spatial information technologies for disaster management in China, in: Showalter, P.S., Lu, Y. (Eds.), Geospatial techniques in urban hazard and disaster analysis. Springer, New York, pp. 245-254.

Moudon, A.V., Kavage, S.E., Mabry, J.E., Sohn, D.W., 2005. A transportation-efficient land use mapping index. Transportation Research Record: Journal of the Transportation Research Board, 1902, 134-144.

Nanjing Shi difangzhi bianzuanweiyuanhui, 2008. Nanjing chengshi guihuazhi (Nanjing Urban Planning). Jiangsu renmin chubanshe, Nanjing. [in Chinese].

National Bureau of Statistics (NBS), 2010a. Zhongguo huanjing tongji nianjian 2009 (China Statistical Yearbook on Environment 2009). Zhongguo tongji chubanshe, Beijing. [in Chinese].

National Bureau of Statistics (NBS), 2011b. Zhongguo huanjing tongji nianjian 2010 (China Statistical Yearbook on Environment 2010). Zhongguo tongji chubanshe, Beijing. [in Chinese].

National Bureau of Statistics (NBS), 2011c. Zhongguo tongji nianjian 2010 (China Statistical Yearbook 2010). Zhongguo tongji chubanshe, Beijing. [in Chinese].

Noy, I., 2009. The macroeconomic consequences of disasters. Journal of Development Economics, 88(2), 221-231.

Shanghai Shi chengshi guihua guanliju, 2006. Shanghai chengshi guihua (Shanghai Urban Planning). Shanghai Shi chengshi guihua guanliju, Shanghai. [in Chinese]. 
Shanghai Shi difangzhi bangongshi, 1997. Shanghai chengshi guihua zhi (Shanghai Urban Planning). http://www.shtong.gov.cn/ (accessed on February 20, 2012). [in Chinese].

Shanghai Shi tongjijubian, 2012. Shanghai tongji nianjian (Shanghai Statistical Yearbook 2011). Shanghai renmin chubanshe, Shanghai. [in Chinese].

Shanghai Water Authority, 2006. Regulations of Shanghai Municipality on the Administration of Water Supply. http://www.shanghaiwater.gov.cn/ (accessed on July 21, 2012).

Skidmore, M., Toya, H., 2002. Do natural disasters promote long-run growth? Economic Inquiry, 40(4), 664-687.

Smith, K., 1996. Environmental hazards: assessing risk and reducing disaster. New York: Routledge.

Smith, V.K., Carbone, J.C., Pope, J.C., Hallstrom, D.G., Darden, M.E., 2006. Adjusting to natural disasters. Journal of Risk and Uncertainty, 33(1), 37-54.

Sun, S., Mao, R., 2008. An introduction to Lake Taihu, in: Qin, B. (Eds.), Lake Taihu, China: dynamics and environmental change. Springer, London, pp. 1-68.

Syvitski, J.P.M. et al., 2009. Sinking deltas due to human activities. Nature Geoscience, 2(10), 681-686.

Taihu Basin Authority, 2000. Taihusheng taihuanjing dituji (Atlas of Ecology and Environment of Taihu Lake). Chinese Academy of Sciences, Beijing. [in Chinese].

University of Michigan China Data Center, 2007. Population grid data 2000 with ownership boundary maps (Shanghai, Jiangsu, Zhejiang, and Anhui) http://www.cartographic.com/ (accessed on September 1, 2009).

Weiss, J.L., Overpeck, J.T., Strauss B., 2010. Mapping areas potentially impacted by sea level rise. http://www.geo.arizona.edu/ (accessed on December 1, 2011).

World Bank, 2006. Hazards of nature, risks to development: an IEG evaluation of World Bank assistance for natural disasters. World Bank, Washington, DC.

Wu, J., Shi, X., Xue, Y., Zhang, Y., Wei, Z., Yu, J., 2008. The development and control of the land subsidence in the Yangtze Delta, China. Environmental Geology, 55(8), 1725-1735.

Xiang, W.N., Stuber, R.M.B., Meng, X., 2011. Meeting critical challenges and striving for urban sustainability in China. Landscape and Urban Planning, 100(4), 418-420.

Yang, H.T., 2007. Natural disaster in China, in: Stoltman, J.P., Lidstone, J., DeChano, L.M. (Eds.), International perspectives on natural disasters: occurrence, mitigation, and consequences. Springer, Dordrecht, pp. 181-192.

Yeh, A.G., Wu, F., 1998. The transformation of the urban planning system in China from a centrally-planned to transitional economy. Progress in Planning, 51, 165-252.

Zhejiang Sheng tongjijubian, 2012. Zhejiang tongji nianjian 2011 (Zhejiang Statistical Yearbook 2011). Zhongguo tongji chubanshe, Beijing. [in Chinese].

Zhongguo chengshi dituji bianji weiyuanhui, 1994. Zhongguo chengshi dituji (Atlas of Cities of China). Zhongguo ditu chubanshe, Xi'an. [in Chinese]. 


\section{List of Tables}

Table 1. History of master plans in Shanghai, 1950-present.

Note: In this paper, Shanghai chengshi zongti guihua fangan, approved in 1986, was adopted for analysis. This plan represents a major breakthrough in the second spring period of China's urban planning due to its comprehensive contents.

Source: Shanghai Shi difangzhi bangongshi (1997), Shanghai Shi chengshi guihua guanliju (2006).

Table 2. Data sources on environmental hazards and land cover.

${ }^{\text {a }}$ Estimated based on Bakun et al. (2005).

${ }^{\mathrm{b}}$ Estimated based on Taihu Basin Authority (2000).

${ }^{\mathrm{c}}$ Original data sources are as follows: Landsat Orthorectified Multispectral Scanner (MSS; $57 \mathrm{~m}$ resolution, recorded in August 1979) and Enhanced Thematic Mapper Plus (ETM+; 30 m resolution, recorded in July 2001) acquired from the US Geological Survey (USGS) Earth Resources Observation and Science Center. Before performing analysis, these remote-sensed images were geometrically rectified, re-projected, and re-sampled using ERDAS Imagine (Hexagon Group, Stockholm, Sweden) with a 100 meter resolution.

Table 3. Environmental disasters in China, 2000-2010.

Note: Percentage of affected areas by flood and drought was calculated based on China's total land area of 9.6 million $\mathrm{km}^{2}$.

Source: NBS (2010a, 2011b, 2011c).

Table 4. Multiple regression estimates of urban lands in high-risk areas in the Yangtze River Delta region.

Note: The correlation coefficients of listed variables were calculated using multiple regression analysis. The dependent variable is the variance in the urban built-up land areas located in highrisk sites divided by the total urban lands of cities (unit: $\mathrm{km}^{2}$ per $100 \mathrm{~km}^{2}$ of urban lands). Highrisk areas were defined by the top $25 \%$ of pixels with the highest value of cumulative environmental risk scores in the region. In the table, the correlation coefficients of listed variables are shown without parentheses and heteroskedastic consistent standard errors are shown in parentheses. The significance level is as follows: ${ }^{*} p<0.10,{ }^{*} p<0.05$.

Source: Zhongguo chengshi dituji bianji weiyuanhui (1994), Jianshebu zonghe caiwusibian (2006), NBS (2010a, 2011b, 2011c).

Table 5. Multiple regression estimates with backward elimination using different definitions of a high-risk area. 
Note: The correlation coefficients of listed variables were calculated using multiple regression analysis with backward elimination. The variables were retained at the $10 \%$ significance level. High-risk areas were defined by three different definitions for sensitivity analysis: the top 15\%, $25 \%$, and $50 \%$ of pixels with the highest value of cumulative risk scores in the region. 


\section{Table 1}

History of master plans in Shanghai, 1950-present.

\begin{tabular}{c|c|l}
\hline Period & $\begin{array}{c}\text { Year of } \\
\text { approval }\end{array}$ & \multicolumn{1}{c}{ Title of master plan } \\
\hline $\begin{array}{l}\text { 1950s- } \\
\text { 1970s }\end{array}$ & 1953 & Chengshi zongtu guihua (Schematic map of city) \\
\cline { 2 - 3 } & 1955 & $\begin{array}{l}\text { Shanghai 1956-1967 nian jinqi guihua caoan (Draft proposal for 1956-1967 } \\
\text { short-term urban planning of Shanghai) }\end{array}$ \\
\cline { 2 - 3 } & 1959 & $\begin{array}{l}\text { Guanyu Shanghai chengshi zongti guihua de chubu yijian (Preliminary views } \\
\text { on the master planning of Shanghai) }\end{array}$ \\
\cline { 2 - 3 } & 1978 & $\begin{array}{l}\text { Guanyu jiaqiang chengshi jianshe gongzuo de yijian (Views on strengthening } \\
\text { urban construction) }\end{array}$ \\
\cline { 2 - 3 } 1980s & 1986 & $\begin{array}{l}\text { Shanghai chengshi zongti guihua fangan (Scheme of urban master plan for } \\
\text { Shanghai) }\end{array}$ \\
\cline { 2 - 3 } & 1991 & $\begin{array}{l}\text { Shanghai chengshi wenhua mingcheng baohu guihua (Shanghai urban } \\
\text { conservation plan) }\end{array}$ \\
\cline { 2 - 3 } & 1993 & $\begin{array}{l}\text { Pudong xinqu zongti guihua (Pudong New Town master plan) } \\
\text { Hongqiao International Airport) }\end{array}$ \\
\hline \multirow{2}{*}{$\begin{array}{l}\text { 1990s- } \\
\text { present }\end{array}$} & 2001 & $\begin{array}{l}\text { Shanghai shi chengshi zongti guihua 1999-2020 (Shanghai urban master plan } \\
\text { 1999-2020) }\end{array}$ \\
\cline { 2 - 3 } & 2009 & \begin{tabular}{l} 
Shanghai shi jinqi jianshe guihua (Shanghai contemporary construction plan) \\
\hline
\end{tabular}
\end{tabular}

Note: In this paper, Shanghai chengshi zongti guihua fangan, approved in 1986, was adopted for analysis. This plan represents a major breakthrough in the second spring period of China's urban planning due to its comprehensive contents.

Source: Shanghai Shi difangzhi bangongshi (1997), Shanghai Shi chengshi guihua guanliju (2006). 


\section{Table 2}

Data sources on environmental hazards and land cover.

\begin{tabular}{|c|c|c|c|c|c|}
\hline \multicolumn{2}{|c|}{ Data } & Original data & Threshold & Years & Data sources \\
\hline \multirow{5}{*}{ 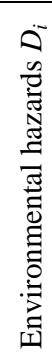 } & Earthquake $\left(D_{1}\right)$ & $1: 4,000,000$ & $30 \mathrm{~km}^{\mathrm{a}}$ & 1979 & $\begin{array}{l}\text { Guojia dizhenju dizhiyanjiusuo (1979); Earthquake } \\
\text { events were collected from USGS Earthquake Hazards } \\
\text { Program 1973-Present. }\end{array}$ \\
\hline & Flood-prone area $\left(D_{2}\right)$ & $1 \mathrm{~km}^{2}$ & $10 \mathrm{~km}^{\mathrm{b}}$ & 2000 & Taihu Basin Authority (2000) \\
\hline & Landslide $\left(D_{3}\right)$ & $100 \mathrm{~m}$ & $1 \mathrm{~km}$ & 2010 & $\begin{array}{l}\text { Estimated based on NASA Shuttle Radar Topography } \\
\text { Mission (SRTM) DEM data 2000; Gupta and Joshi } \\
\text { (1990) }\end{array}$ \\
\hline & Land subsidence $\left(D_{4}\right)$ & $1: 2,000,000$ & $1 \mathrm{~km}$ & 2008 & Wu et al. (2008) \\
\hline & Sea-level rise $\left(D_{5}\right)$ & $1 \mathrm{~km}^{2}$ & $1 \mathrm{~km}$ & 2010 & Gu et al. (2010); Weiss et al. (2010) \\
\hline \multirow{6}{*}{$\begin{array}{l}\text { च } \\
0 \\
0 \\
0 \\
0 \\
0 \\
0 \\
0 \\
0 \\
0\end{array}$} & Forest $\left(L_{1}\right)$ & \multirow{6}{*}{$30 \mathrm{~m}$ (rescale } & \multirow{6}{*}{$100 \mathrm{~m})$} & \multirow{6}{*}{$\begin{array}{l}1979, \\
2000\end{array}$} & USGS 1979, 2000'; Google Earth \\
\hline & Cultivated land $\left(L_{2}\right)$ & & & & USGS 1979, 2000; Google Earth \\
\hline & Cash-crop field $\left(L_{3}\right)$ & & & & $\begin{array}{l}\text { Guojia dituji bianzuan weiyuanhui (1993); USGS } \\
1979,2000^{\mathrm{C}}\end{array}$ \\
\hline & Wetland $\left(L_{4}\right)$ & & & & USGS 1979, 2000 ; Gong et al. (2010) \\
\hline & Water body $\left(L_{5}\right)$ & & & & $\begin{array}{l}\text { USGS 1979, 2000; Changjiang Water Resources } \\
\text { Commission (1999) }\end{array}$ \\
\hline & All other lands $\left(L_{6}\right)$ & & & & USGS 1979, 2000 ; Google Earth \\
\hline
\end{tabular}

${ }^{\mathrm{a}}$ Estimated based on Bakun et al. (2005).

${ }^{\mathrm{b}}$ Estimated based on Taihu Basin Authority (2000).

${ }^{\mathrm{c}}$ Original data sources are as follows: Landsat Orthorectified Multispectral Scanner (MSS; $57 \mathrm{~m}$ resolution, recorded in August 1979) and Enhanced Thematic Mapper Plus (ETM+; 30 m resolution, recorded in July 2001) acquired from the US Geological Survey (USGS) Earth Resources Observation and Science Center. Before performing analysis, these remote-sensed images were geometrically rectified, re-projected, and re-sampled using ERDAS Imagine (Hexagon Group, Stockholm, Sweden) with a 100 m resolution. 
Table 3

Environmental disasters in China, 2000-2010.

\begin{tabular}{|c|c|c|c|c|c|c|c|c|c|}
\hline \multirow[b]{2}{*}{ Year } & \multicolumn{3}{|c|}{$\begin{array}{l}\text { Geological Disaster } \\
\text { (number of events) }\end{array}$} & \multicolumn{2}{|c|}{$\begin{array}{c}\text { Earthquake } \\
\text { (number of events) }\end{array}$} & \multicolumn{2}{|c|}{ Flood } & \multicolumn{2}{|c|}{ Drought } \\
\hline & $\begin{array}{c}\text { Landslide } \\
\text { and } \\
\text { collapse } \\
\end{array}$ & $\begin{array}{l}\text { Mud- } \\
\text { rock } \\
\text { flow } \\
\end{array}$ & $\begin{array}{c}\text { Land } \\
\text { subsidence }\end{array}$ & $\begin{array}{c}\text { M 5.0-6.0 } \\
\text { Richter } \\
\text { scale } \\
\end{array}$ & $\begin{array}{c}\mathrm{M}>6.0 \\
\text { Richter } \\
\text { scale } \\
\end{array}$ & $\begin{array}{c}\text { Affected } \\
\text { areas } \\
(1,000 \text { ha }) \\
\end{array}$ & $\begin{array}{l}\% \text { of } \\
\text { China }\end{array}$ & $\begin{array}{c}\text { Affected } \\
\text { areas } \\
\text { (1,000 ha) }\end{array}$ & $\begin{array}{l}\% \text { of } \\
\text { China }\end{array}$ \\
\hline 2000 & 16,376 & 1,958 & 347 & 7 & 2 & 4,321 & 0.45 & 26,784 & 2.78 \\
\hline 2001 & 3,617 & 1,539 & 554 & 8 & 3 & 3,614 & 0.37 & 23,698 & 2.46 \\
\hline 2002 & 34,344 & 4,976 & 521 & 4 & 0 & 7,388 & 0.77 & 13,174 & 1.37 \\
\hline 2003 & 12,844 & 1,549 & 574 & 10 & 7 & 12,289 & 1.27 & 14,470 & 1.50 \\
\hline 2004 & 11,723 & 1,157 & 445 & 8 & 1 & 3,747 & 0.39 & 8,482 & 0.88 \\
\hline 2005 & 17,021 & 566 & 137 & 9 & 2 & 6,047 & 0.63 & 8,479 & 0.88 \\
\hline 2006 & 101,683 & 417 & 398 & 9 & 0 & 4,569 & 0.47 & 13,411 & 1.39 \\
\hline 2007 & 23,200 & 1,215 & 578 & 1 & 1 & 5,105 & 0.53 & 16,170 & 1.68 \\
\hline 2008 & 21,530 & 843 & 454 & 6 & 6 & 3,656 & 0.38 & 6,798 & 0.71 \\
\hline 2009 & 8,688 & 1,442 & 326 & 5 & 2 & 3,162 & 0.33 & 13,197 & 1.37 \\
\hline 2010 & 27,938 & 1,981 & 478 & 4 & 1 & 7,024 & 0.73 & 8,987 & 0.93 \\
\hline
\end{tabular}

Note: Percentage of affected areas by flood and drought was calculated based on China's total land area of 9.6 million $\mathrm{km}^{2}$.

Source: NBS (2010a, 2011b, 2011c). 
Table 4

Multiple regression estimates of urban lands in high-risk areas in the Yangtze River Delta region.

\begin{tabular}{|c|c|c|c|c|c|c|}
\hline \multirow{2}{*}{\multicolumn{2}{|c|}{ Regression models }} & \multirow{2}{*}{$\begin{array}{c}\text { Planning } \\
(1) \\
\end{array}$} & \multicolumn{2}{|c|}{$\begin{array}{l}\text { Planning, municipal services, } \\
\text { demand for hazard mitigation, and } \\
\text { barrier for controlling development }\end{array}$} & \multicolumn{2}{|c|}{ All factors considered } \\
\hline & & & $(2)$ & (3) & (4) & (5) \\
\hline \multirow{5}{*}{$\begin{array}{l}\text { Compliance } \\
\text { with master } \\
\text { plan }\end{array}$} & $\begin{array}{l}\text { Ring road (1 = } \\
\text { compliance) }\end{array}$ & $\begin{array}{l}-1.677 \\
(9.683) \\
\end{array}$ & & & & $\begin{array}{c}7.584 \\
(6.362) \\
\end{array}$ \\
\hline & Block size & $\begin{array}{l}-6.634 \\
(8.383) \\
\end{array}$ & $\begin{array}{l}-7.918 \\
(7.544) \\
\end{array}$ & & $\begin{array}{l}-6.253 \\
(7.689) \\
\end{array}$ & \\
\hline & $\begin{array}{c}\text { Total area of urban } \\
\text { land }\end{array}$ & $\begin{array}{c}0.124 \\
(0.152) \\
\end{array}$ & $\begin{array}{l}0.247^{*} \\
(0.146) \\
\end{array}$ & $\begin{array}{c}0.163 \\
(0.163) \\
\end{array}$ & $\begin{array}{l}0.0995 \\
(0.188) \\
\end{array}$ & $\begin{array}{l}0.00345 \\
(0.197) \\
\end{array}$ \\
\hline & $\begin{array}{l}\text { Location of industry } \\
(1=\text { compliance })\end{array}$ & $\begin{array}{c}10.88 \\
(6.774) \\
\end{array}$ & & $\begin{array}{l}-5.292 \\
(7.185) \\
\end{array}$ & $\begin{array}{c}-8.874 \\
(7.910) \\
\end{array}$ & \\
\hline & $\begin{array}{l}\text { Preservation zoning } \\
\text { (1 = compliance })\end{array}$ & $\begin{array}{c}-12.33^{* *} \\
(5.683) \\
\end{array}$ & $\begin{array}{c}-16.01^{* *} \\
(6.194) \\
\end{array}$ & $\begin{array}{l}-11.02 \\
(6.919) \\
\end{array}$ & $\begin{array}{c}-14.03 * * \\
(5.723) \\
\end{array}$ & $\begin{array}{l}-10.59^{*} \\
(5.522) \\
\end{array}$ \\
\hline \multirow[t]{3}{*}{$\begin{array}{l}\text { Municipal } \\
\text { services }\end{array}$} & Sewer density & & $\begin{array}{l}-0.531 \\
(0.404) \\
\end{array}$ & $\begin{array}{l}-0.898^{*} \\
(0.493)\end{array}$ & $\begin{array}{l}-0.523 \\
(0.538) \\
\end{array}$ & $\begin{array}{l}-0.681 \\
(0.465)\end{array}$ \\
\hline & Road maintenance & & $\begin{array}{l}9.414^{*} \\
(5.344) \\
\end{array}$ & $\begin{array}{c}9.334 \\
(8.355) \\
\end{array}$ & $\begin{array}{l}10.17 * \\
(5.943) \\
\end{array}$ & $\begin{array}{l}11.48 * \\
(6.187) \\
\end{array}$ \\
\hline & Garbage treatment & & & $\begin{array}{l}-5.593 \\
(232.9) \\
\end{array}$ & & $\begin{array}{l}-141.2 \\
(196.2) \\
\end{array}$ \\
\hline \multirow{2}{*}{$\begin{array}{l}\text { Demand for } \\
\text { hazard } \\
\text { mitigation }\end{array}$} & $\begin{array}{l}\text { Historic flood event } \\
(1=\text { yes })\end{array}$ & & & $\begin{array}{l}19.04^{* *} \\
(5.210)\end{array}$ & $\begin{array}{l}13.58^{* *} \\
(5.352) \\
\end{array}$ & $\begin{array}{l}16.64^{* *} \\
(5.856)\end{array}$ \\
\hline & Air pollution & & & $\begin{array}{l}-178.5 \\
(265.6) \\
\end{array}$ & & \\
\hline \multirow[t]{2}{*}{$\begin{array}{l}\text { Economic } \\
\text { resources }\end{array}$} & GDP per capita & & & & $\begin{array}{c}0.000161 \\
(0.000146)\end{array}$ & $\begin{array}{c}0.000182 \\
(0.000164)\end{array}$ \\
\hline & $\begin{array}{l}\text { City status }(1= \\
\text { regional-level city) }\end{array}$ & & & & $\begin{array}{l}-11.57^{*} \\
(6.281) \\
\end{array}$ & $\begin{array}{l}-4.535 \\
(7.307) \\
\end{array}$ \\
\hline \multirow{3}{*}{$\begin{array}{l}\text { Barriers to } \\
\text { controlling } \\
\text { developmen } \\
\text { ts }\end{array}$} & $\begin{array}{l}\text { Presence of mining } \\
\text { site }(1=\text { yes })\end{array}$ & & & & & $\begin{array}{l}-18.33 \\
(13.14)\end{array}$ \\
\hline & $\begin{array}{l}\text { Population growth } \\
\text { rate (\%) }\end{array}$ & & & & & $\begin{array}{l}-0.280 \\
(0.653) \\
\end{array}$ \\
\hline & $\begin{array}{l}\text { Average slope of } \\
\text { lands (degree) }\end{array}$ & & & & & $\begin{array}{c}1.445 \\
(3.864) \\
\end{array}$ \\
\hline & ntercept & $\begin{array}{l}10.97 * \\
(5.997)\end{array}$ & $\begin{array}{c}7.558 \\
(8.903) \\
\end{array}$ & $\begin{array}{c}24.43 \\
(25.84)\end{array}$ & $\begin{array}{c}5.651 \\
(8.799)\end{array}$ & $\begin{array}{l}-1.089 \\
(10.99)\end{array}$ \\
\hline \multicolumn{2}{|c|}{ Adj. R-Square } & 0.083 & 0.193 & 0.280 & 0.314 & 0.286 \\
\hline \multicolumn{2}{|c|}{ Sample size } & 47 & 47 & 47 & 47 & 47 \\
\hline
\end{tabular}

Note: The correlation coefficients of listed variables were calculated using multiple regression analysis. The dependent variable is the variance in the urban built-up land areas located in highrisk sites divided by the total urban lands of cities (unit: $\mathrm{km}^{2}$ per $100 \mathrm{~km}^{2}$ of urban lands). Highrisk areas were defined by the top $25 \%$ of pixels with the highest value of cumulative environmental risk scores in the region. In the table, the correlation coefficients of listed variables are shown without parentheses and heteroskedastic consistent standard errors are shown in parentheses. The significance level is as follows: ${ }^{*} p<0.10,{ }^{*} p<0.05$.

Source: Zhongguo chengshi dituji bianji weiyuanhui (1994), Jianshebu zonghe caiwusibian (2006), NBS (2010a, 2011b, 2011c). 
Table 5

Multiple regression estimates with backward elimination using different definitions of a high-risk area.

\begin{tabular}{l|l|l|l}
\hline Definitions & Significant variables & Regression coefficients & $p>|t|$ \\
\hline \multirow{2}{*}{$\begin{array}{l}\text { Top 15\% risk } \\
\text { scores }\end{array}$} & Preservation zoning & -6.130 & 0.024 \\
\cline { 2 - 4 } & Historic flood event & 7.843 & 0.004 \\
\cline { 2 - 4 } & Road maintenance & 6.617 & 0.048 \\
\hline \multirow{2}{*}{$\begin{array}{l}\text { Top 25\% risk } \\
\text { scores }\end{array}$} & Preservation zoning & -10.624 & 0.046 \\
\cline { 2 - 4 } & Historic flood event & 19.611 & 0.000 \\
\cline { 2 - 4 } & City status & -9.240 & 0.035 \\
\hline \multirow{2}{*}{$\begin{array}{l}\text { Top 50\% risk } \\
\text { scores }\end{array}$} & Ring road & 14.792 & 0.074 \\
\cline { 2 - 4 } & Historic flood event & 33.480 & 0.000 \\
\cline { 2 - 4 } & Presence of mining site & -18.610 & 0.012 \\
\hline
\end{tabular}

Note: The correlation coefficients of listed variables were calculated using multiple regression analysis with backward elimination. The variables were retained at the $10 \%$ significance level. High-risk areas were defined by three different definitions for sensitivity analysis: the top 15\%, $25 \%$, and $50 \%$ of pixels with the highest value of cumulative risk scores in the region. 


\section{List of Figures}

Fig. 1. Selected master plans of the cities in the Yangtze River Delta region in the 1980s. A: Nanjing, B: Hangzhou, C: Changshu.

Note: The scale of the master plans varies between 1:28,000 and 1:140,000. Each plan was labeled with land-use classifications such as residential (yellow), central (red), service (orange), industry (brown), storage (purple), transport (grey pattern), rotary, government (dark green), preservation (light green), and water-body (light blue) zones. For land-cover layers, Landsat remote-sensed images were used for supervised classification by utilizing a maximum likelihood classifier in Multispec with a $100 \mathrm{~m}^{2}$ resolution. Urban land, agricultural land, rangeland, forest, water bodies, wetland, and barren land were extracted from the original images. Finally, land in the study area was subdivided into $1 \mathrm{~km}^{2}$ grid cells so that a dominant land-cover type within each cell can be recorded in ArcGIS. Each black dot in the figure represents $1 \mathrm{~km}^{2}$ of urban builtup land that had been converted from non-urban land since 1980.

Source: Zhongguo chengshi dituji bianji weiyuanhui (1994).

Fig. 2. The theoretical process of environmental risk modeling.

Note: Five raster-type hazard layers were digitized and georeferenced to the original map's coordinate system using five control points per image. Original raster data was chosen based on its spatial resolution $\left(<1 \mathrm{~km}^{2}\right)$, regional coverage (equal or larger than the Yangtze River Delta region), and data availability.

Fig. 3. Environmental risk map of the Yangtze River Delta region.

Note: Each dot represents the location of 47 cities and towns. Their names are as follows. 1: Shanghai, 2: Chengqiaozhen, 3: Huinanzhen, 4: Jiangchuanjiedao, 5: Songjiangzhen, 6: Zhujingzhen, 7: Jinshanweizhen, 8: Qingpuzhen, 9: Kunshan, 10: Yongzhizhen, 11: Suzhou, 12: Dongshanzhen, 13: Mochengzhen, 14: Changshu, 15: Gangxiazhen, 16: Zhangjiagang, 17: Wuxi, 18: Changzhou, 19: Jiangyin, 20: Danyang, 21: Guanlinzhen, 22: Heqiaozhen, 23: Yichengzhen, 24: Yixing, 25: Zhenjiang, 26: Nanjing, 27: Yizheng, 28: Yangzhou, 29: Xiongzhouzhen, 30: Lukouzhen, 31: Yongyangzhen, 32: Chunxizhen, 33: Huzhou, 34: Tangxizhen, 35: Linpingzhen, 36: Jiaxing, 37: Haining, 38: Hangzhou, 39: Dangshanzhen, 40: Shaoxing, 41: Cixi, 42: Ningbo, 43: Zhoushan, 44: Pingchaozhen, 45: Luqiaozhen, 46: Nantong, 47: Qidong.

Fig. 4. Histogram of environmental risk scores describing land areas in different risk groups in the Yangtze River Delta region.

Note: Histogram bars (x-axis) are displayed by $1 \%$ of area ratio in the order of environmental risk scores calculated based on formula (2) in the article.

Fig. 5. Ranks of cities and towns in the Yangtze River Delta region by their percentage of urban 
lands in high-risk areas.

Note: Three different definitions of high-risk zones- $50 \%, 25 \%$, and $15 \%$ of the region's total lands-were used in the analysis. The Y-axis is the percentage of urban lands located in high-risk zones as specified by all three definitions. The $\mathrm{X}$-axis represents the ranks of 47 cities and towns arranged in descending order based on the $25 \%$ definition. The top ten ranked cities and towns are as follows: Dongshanzhen (1), Chengqiaozhen (2), Mochengzhen (3), Tangxizhen (4), Zhujingzhen (5), Huinanzhen (6), Kunshan (7), Huzhou (8), Yongzhitown (9), Jinshanweizhen (10).

Fig. 6. Histogram of the distribution of urban lands in high-risk areas. The distribution is represented by the distance $(\mathrm{km})$ of $1 \mathrm{~km}^{2}$ urban land pixels from the city centers of Hangzhou, Nanjing, Shanghai, and Wuxi. 


\section{Acknowledgements}

The environmental suitability model was developed by the authors working in a research group directed by Professor Peter Rowe at the Harvard University Graduate School of Design. Data collection and collaborative geospatial database building was funded by the East-West Cultural Development Center and Foundation and the Association for Asian Studies. Part of the analyses were presented and refined through in-depth discussion in a research seminar at Harvard entitled "Urban Formation and Spatial Analysis in East Asian Cities." This seminar course was sponsored by the Eugene Group in South Korea since 2011. 


\section{Original hazard data}

\section{Rescaled data}

Land-cover layer

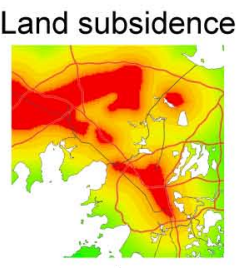

I

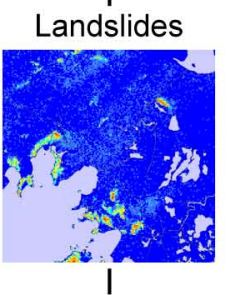

Earthquake
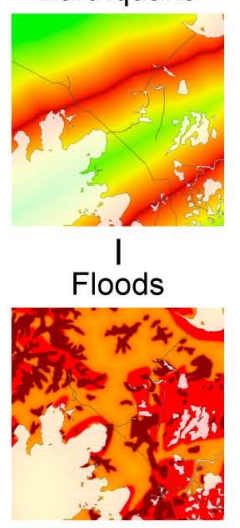

Sea-level rise

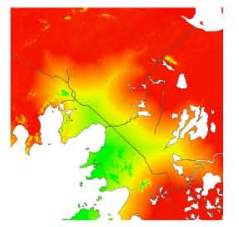

\section{Land subsidence}

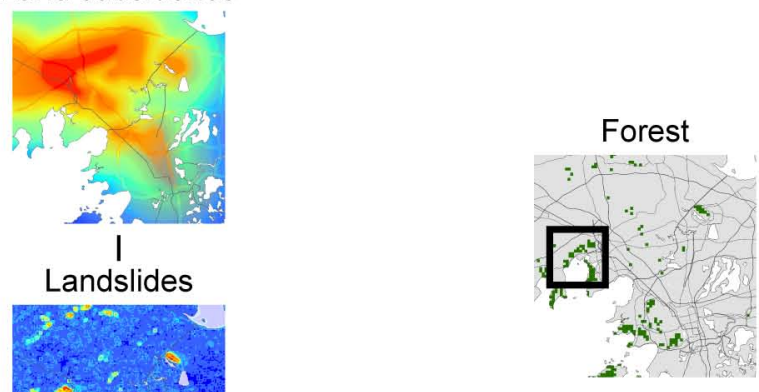

Paddy fields

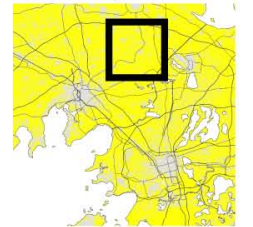

log-
transformed
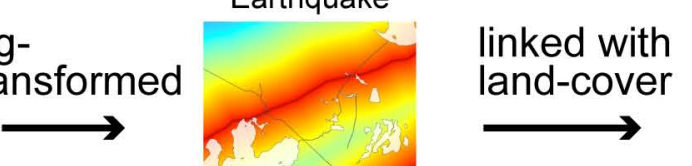

\section{Cash-crop fields}

land-cover
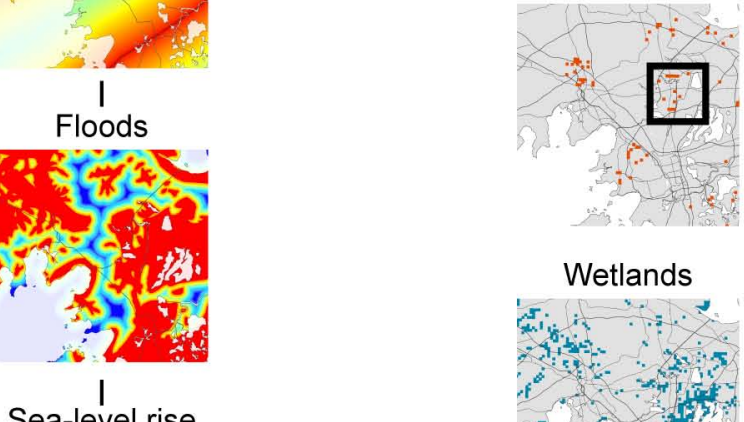

Sea-level rise
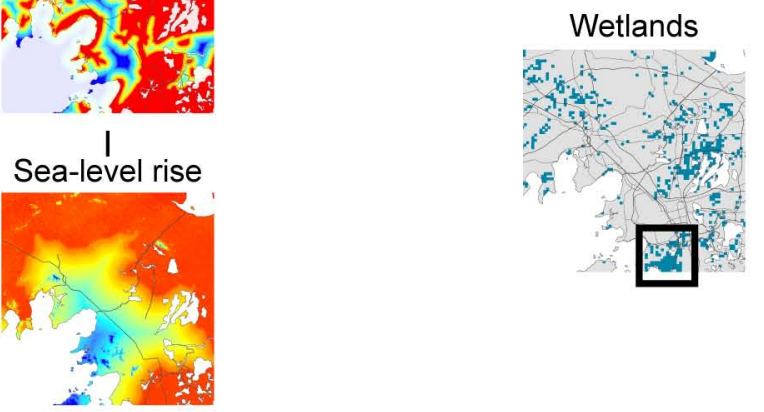

weighted

sum

with risk scores

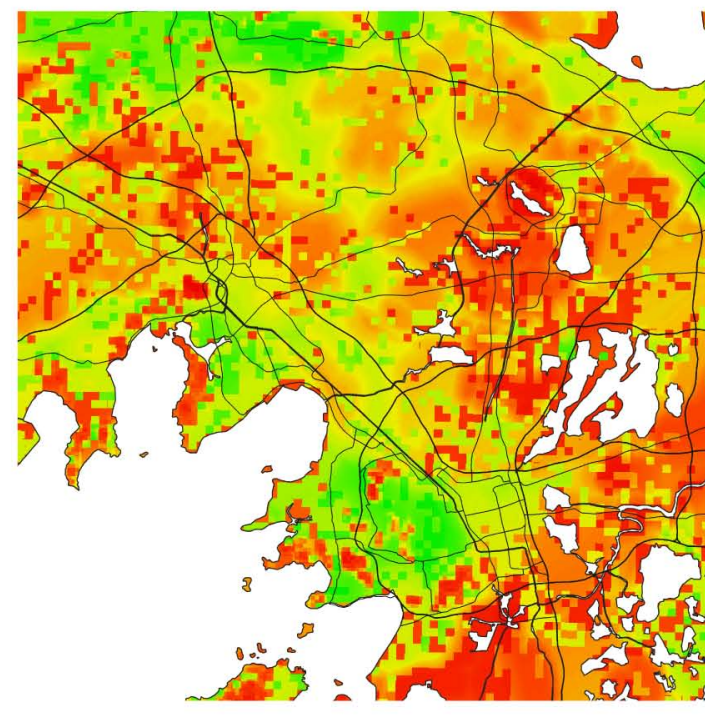

Logistic transformation of rarity-based Index rarity

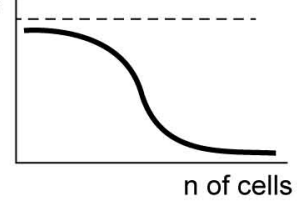




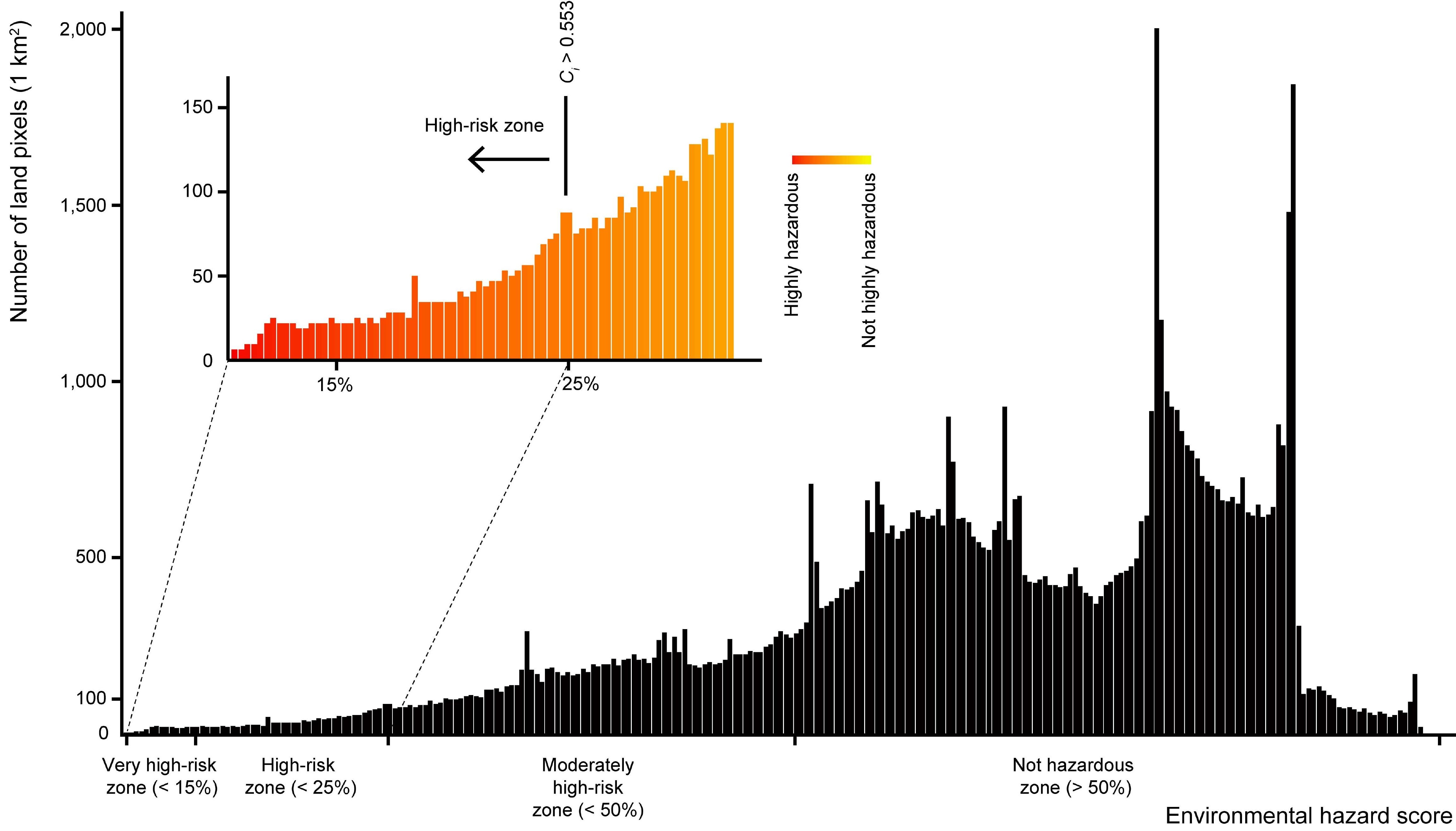




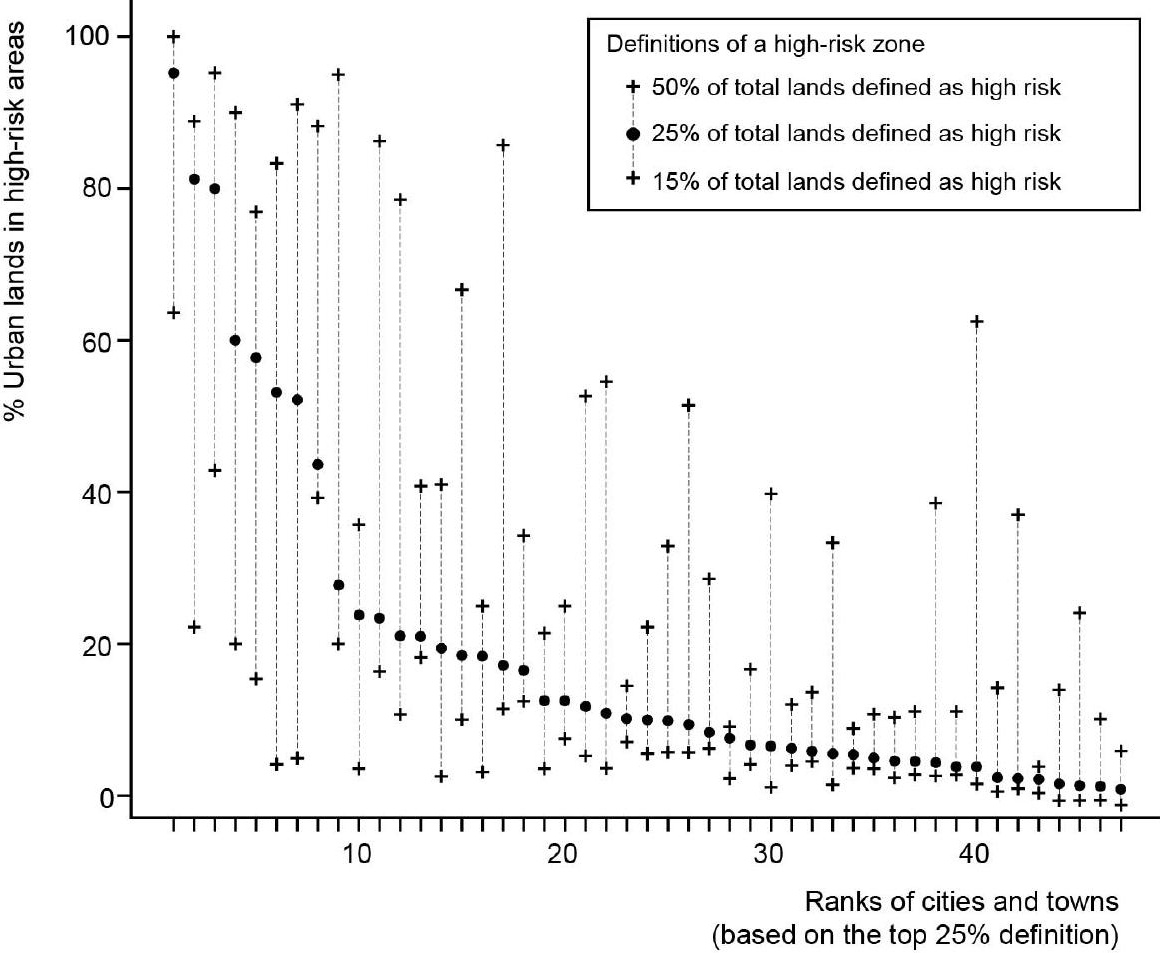




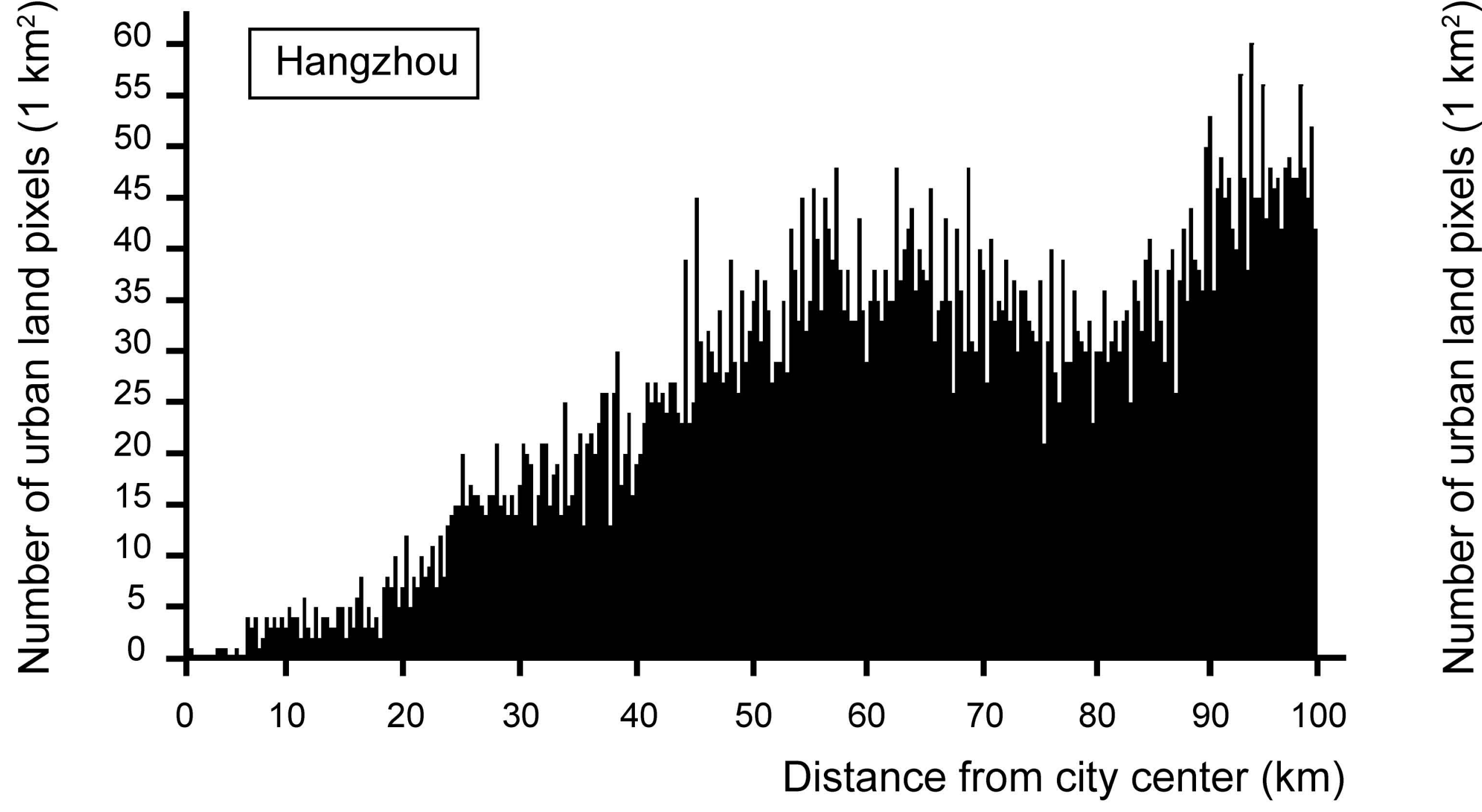

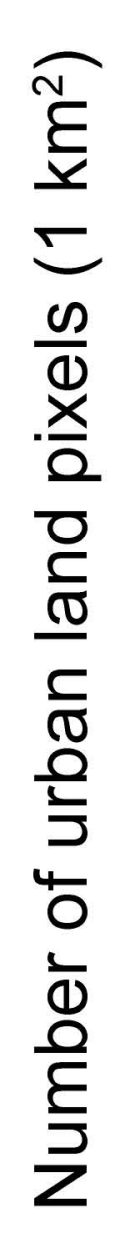

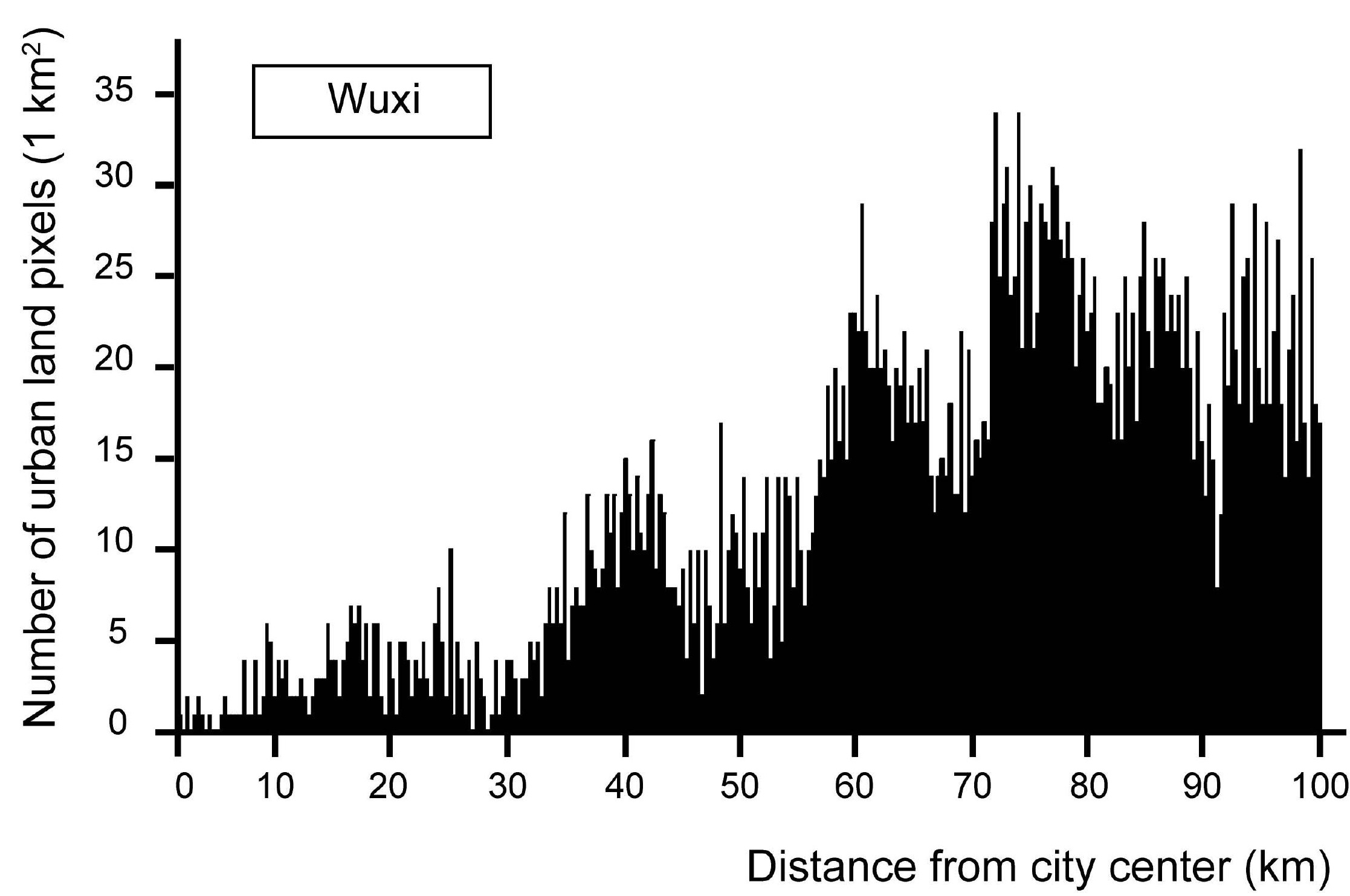

